\title{
The story of the Department of Practical Theology
}

Authors:

Elsje P. Büchner ${ }^{1}$

Julian C. Müller ${ }^{1}$

\section{Affiliations:}

${ }^{1}$ Department of Practical

Theology, University of

Pretoria, South Africa

\section{Correspondence to:}

Julian Müller

e-mail:

julian.muller@up.ac.za

Postal address:

PO Box 626, Wapadrand,

Pretoria, 0050, South Africa

\section{Keywords:}

Department of Practical

Theology; Faculty of

Theology; University

of Pretoria; missiology;

theological teaching

\section{Dates:}

Received: 01 Dec. 2008

Accepted: 15 Jan. 2009

Published: 17 Dec. 2009

How to cite this article: Büchner, E.P. \& Müller, J.C., 2009, 'The story of the Department of Practical Theology', Verbum et Ecclesia 30(3), Art. \#153, 5 pages.

DOI: 10.4102/ve.v30i3.153

This article is available at:

http://www.ve.org.za
(C) 2009. The Authors. Licensee: OpenJournals Publishing. This work is licensed under the Creative Commons Attribution License.

\section{ABSTRACT}

This article tells the story of the development of the Department of Practical Theology of the Faculty of Theology at the University of Pretoria. The story goes back to the start of the Faculty in 1938, although the Department of Practical Theology was only established in 1966 when Professor H.D.A. du Toit applied himself fully to the subject and Professor C.W.H. Boshoff became the first full-time lecturer for Missiology. The article is written mainly from the perspective of the Dutch Reformed Church, but with the acknowledgement of the appointments of Professor Yolanda Dreyer from the Nederduitsch Reformed Church of Africa and Professor Maake Masango from the Uniting Presbyterian Church of Southern Africa.

\section{INTRODUCTION}

\section{A theological faculty at the University of Pretoria: A stormy beginning}

In 1938, at the wake of Afrikaner Nationalism, the Faculty of Theology at the University of Pretoria came into being. The laying of the cornerstone of the Voortrekker Monument in this year caused great excitement, and the symbolic ossewatrek across South Africa created much enthusiasm for the sake of Afrikaner Nationalism. However, this time also witnessed a drastic process of urbanisation, which left its marks especially in the north of the country ( $c f$. Büchner 2007:89-90 for a historical overview of the period 1925-1948).

The South African Church Council was established in 1936, and in 1941 the Dutch Reformed Church (DRC) withdrew from this clerical body. Due to the Du Plessis issue, which started in 1928, relationships between the DRC in the Cape and in the then Transvaal were uneasy (Hofmeyr 2002:178). The establishment of the Faculty of Theology of the DRC (then known as Section B of Theology) at the University of Pretoria should be understood against this background.

Historians describe the establishment of the Faculty as a story of struggle and opposition (Van der Watt 1987:170-177). At that time, the Transvaal Church committed the training and legitimisation of its ministers to the Church of the Cape, initially preferring to maintain a distance. In the process, the DRC lost potential ministers because Stellenbosch in the Cape, where this training and legitimisation took place, was so far away. Due to distance and costs, young men preferred to study at the Theological School of Reformed Churches in South Africa at Potchefstroom or at the Theological Faculty of the Netherdutch Reformed Church of South Africa, then already established at the University of Pretoria. Initial pleas fell onto deaf ears, the assumed reason being that yet another faculty would weaken the federal relationship between the DR churches and wreck the ideal of final church union (Van der Watt 1987:173).

When the matter regarding the necessity of an own theological faculty for the DRC was raised, the main question was to which extent the Church would be able to provide its members with the 'best guidance'. Although the synod in 1925 objected to the appointment of clerical professors, the Commission pointed out that through its faculty, the Netherdutch Reformed Church was able to exert a remarkable influence in the University (Van der Watt 1987:173).

In 1934 the issue regarding an own theological faculty was raised once again at the synod of the DRC in Transvaal (Van der Watt 1987:174-175). The reasons put forward were among others that such a faculty would be able to exert more influence on Afrikaans students, but even more importantly, that it would be in the interest of effective training of ministers for the north (or the then Transvaal) with its unique context, namely industries, black people, instead of coloured people as in the Cape, and other church denominations (cf. Hofmeyr 2002:178). During the report of 1937, the unique circumstances in the then Transvaal were mentioned again at the Transvaal Synod of 1937 (Van der Watt 1987:177). The Church evidently felt the need for theology to provide specific answers to the contextual questions of the day.

On 16 March 1938 the Theological Faculty (Dutch Reformed Section B) became a reality and the first four professors were appointed in the church building of Pretoria East. They were G.M. Pellisier for Dogmatics, D.J. Keet for Church History, E.P. Groenewald for New Testament and J.H. Kritzinger for Old Testament. These four lecturers had to pay attention to undergraduate training and the content and planning of the courses (Van der Watt 1987:178). From the start, scriptural exegesis received special emphasis (Van der Watt 1987:179).

\section{THE DEPARTMENT OF PRACTICAL THEOLOGY IS ESTABLISHED}

Since the beginning the Faculty of Theology (Section B) concentrated on two main points: biblical theology and contextual theology. With the strong emphasis on the context in the north and the importance of a faculty within these industrialised surroundings, practical subjects became increasingly important and necessarily had to receive more attention.

In 1948 a fifth department was created, namely Science for Religion and Missiology. In 1953 Professor H.D.A. du Toit joined ranks with the lecturers as head of Science for Religion and Missiology with the 
task to manage Missiology and Practical Theology simultaneously (Van der Watt 1987:181). Therefore, practical theology only later received attention as an independent discipline. Van der Watt (1987:181) justly states that Missiology and Practical Theology were emphasised as important and unique subject matters in due course; however, these subjects would show to better advantage only if they were separated and assigned to separate lecturers.

In 1966, at request of the Church, the University Board granted that two separate lectures be appointed for Missiology and Practical Theology (Van der Watt 1987:181). Professor H.D.A du Toit now applied himself to Practical Theology and was instrumental in the development of this department into an independent one (Jordaan 1976:41). He was head of the Department until his retirement in 1972, while Professor. C.W.H. Boshoff occupied the chair for Missiology since 1967 (Jordaan 1976:41; Kellerman 1989:1)

Prof. H.D.A. du Toit completed his doctoral exams at the Vrije Universiteit van Amsterdam (Free University of Amsterdam) and in 1948 his doctoral degree was conferred by the University of Pretoria. His dissertation pertained to preachers and their preaching in the DRC of South Africa in 1662 to 1860 (Jordaan 1976:41)

Du Toit's most important contributions were the establishment of new liturgical orders, inventive formularies and day-to-day preaching for the DRC. Furthermore he also made contributions to the broader field of practical theology, missiology and charity, by means of publications in Deur woord en skrif (Through word and script) and during discussions at synods (Jordaan 1976:41). $\mathrm{Du}$ Toit also wrote a number of popular religious books and articles and was involved in church ministry. A short time before his death he was still attached to the then Evangelisation Consulting Rooms in Pretoria, which kept him close to church practice. At the end of 1972 he accepted emeritus status and passed away in 1976 (Jordaan 1976:41).

These first 10 years can be described as the establishment years of the Department of Practical Theology. This was the time when the focus of the Department was mainly on church ministry. Yet $\mathrm{Du}$ Toit made students aware of the demands within the community. For example, besides the books that he prescribed, he took the initiative to encourage a group of students to attend the first National Congress on Church and Industry in Johannesburg in 1970.

\section{DEVELOPMENT OF THE SUBJECT OF PRACTICAL THEOLOGY UNDER THE GUIDANCE OF PROFESSOR J.J. DE KLERK}

The person who was responsible for the fundamental establishment of practical theology as a theological discipline was Professor J.J. (Mias) de Klerk. This was probably due to his broad academic background and especially his exposure to the humanities.

In 1965 De Klerk obtained an MA degree in sociology and received his doctoral degree in the sociology of religion in 1967 at the Potchefstroom University for Christian Higher Education (now the University of the North West). In 1972 he obtained a DTh degree in pastoral care at Stellenbosch University (Kellerman 1989:2). On 20 February 1973 he accepted an appointment as professor in Practical Theology at the Theological Faculty (Section B) in the place of Professor H.D.A. du Toit (Van der Merwe \& Viljoen 1999:347).

De Klerk published various books relevant to his task as lecturer during his academic career. The most well-known publications during his period of service at the University of Pretoria are Kerklike dienswerk (1974), Weldadigheid en mededeelsaamheid (1976), Prediking (1977), Herderkunde (1978) and Evangelistiek (as editor and contributor in 1979). His inaugural speech in 1973 pertained to a homiletic reappreciation of preaching from the point of view of the Kingdom (Kellerman 1989:2). He also published in other books and wrote many academic as well as popular articles.

His most important contribution as academic at the University of Pretoria's Department of Practical Theology was in the area of preaching and the fundamental establishment of the official services of the church (cf. also Kellerman 1989:2).

De Klerk moved to Bloemfontein in August 1980, after accepting the offer to become the first professor at the Department of Deaconology and dean of the newly established Theological Faculty at the University of the Orange Free State (now the University of the Free State) (Kellerman 1989:1; Van der Merwe \& Viljoen 1999:347).

\section{FURTHER EXPANSION}

During the seventies the numbers of students and lecturers increased vastly (Hofmeyr 2002:179). The Department of Practical Theology would benefit by this increase in student numbers. Consequently Prof. Dr A.C. (Attie) Barnard accepted an appointment as senior lecturer in Practical Theology in 1976. At first he worked alongside De Klerk and later succeeded him as head of the Department.

Barnard was a specialist in liturgy and his many publications on preaching and liturgy reveal his most important legacy. His book Die erediens (Public Worship) is a monumental work for which he received the Andrew Murray award. Like Du Toit he also studied at the Free University of Amsterdam and obtained his doctoral degree in Official Theology on Pentecost in the Church Year in 1954. Thereafter he served in various congregations before accepting the appointment at the University of Pretoria. He retired in 1990.

During this time a second full-time lecturer was appointed in the Department. It was the task of Professor Albertus Smuts to lecture on both pastoral care and the deaconate. Unfortunately, he had to retire after a short period of service due to failing health.

In 1976 Dr H.J.C. (Hennie) Pieterse was added to the rank of the lecturers at the Department of Practical Theology. Within 10 years the manpower of this department developed from a shared professorship to three lecturers!

After Dr Pieterse accepted a post as lecturer at the University of South Africa (Unisa), Dr M. (Malan) Nel was appointed in 1980 as senior lecturer for Practical Theology. Nel was the vice-leader of the well-known Youth-to-Youth movement in 1974, and thereafter student minister of the DR parish Universiteitsoord for two years.

Nel brought a new dimension to the Department with his vast experience in youth ministry and his interest in evangelisation. Consequently, in 1982 he obtained his doctoral degree in youth evangelism. Hereafter he was appointed as co-professor at the Department until 1988 and then became attached to the Department of Biblical Studies at Vista University. In 1994 he returned to establish the Centre for Contextual Ministry at the Faculty of Theology.

\section{THE NINETIES - A DEPARTMENT OF INTERNATIONAL RECOGNITION}

The two decades following the appointments of Professor C.J.A. (Cas) Vos in 1989, Professor J.C. (Julian) Müller in 1990 and Dr H.S. (Herman) Breytenbach in 1991 were golden years for the Department of Practical Theology. Breytenbach left the Department and the service of the DRC in 1993 (Dutch Reformed Church 2008:284). Vos and Müller left impressions of their individuality in unique ways and established valuable international contacts. Vos with his artisticity, literary talent and poetical abilities soon made remarkable contributions nationally 
and internationally in the fields of homiletics and liturgy. Müller applied himself to the narrative approach in pastoral therapy and practical theology. With the establishment of master's and doctoral courses in these fields, he soon established a school of thought that is recognised internationally today. Professor Gerben Heitink of the Free University of Amsterdam and a world-famed practical theologian became a friend and fellow research partner of both Vos and Müller. In a recent article (Heitink 2008:418) he writes about the narrative tradition that is also accepted in South Africa and mentions the publication $\mathrm{Om}$ tot verhaal te kom (To come to your wits again). Heitink also refers to the hermeneutical contributions made by H.J.C. Pieterse and C.J.A. Vos.

\section{Professor Cas Vos \\ Background}

Professor C.J.A. Vos joined the Department of Practical Theology in January 1989. Although he obtained his doctoral degree in dogmatics, he was nevertheless appointed as co-professor in Practical Theology and became professor and head of the Department following Professor Attie Barnard's retirement.

Vos immediately applied himself to homiletics and liturgy and made his mark locally and internationally. During 1990 he was chair of the Homiletic Working Group in Pretoria, member of the international association Arbeitsgemeinschaft für Homiletik and co-editor of a homiletic series entitled God, Mens en die Wêreld (God, Humans and the World). Furthermore, he served on the editorial boards of several academic publications such as Skrif en Kerk (Scripture and Church) and Praktiese Teologie in Suid-Afrika (Practical Theology in South Africa) as well as a textbook series for practical theology in South Africa.

Vos has also been active in clerical matters and during the nineties he was a member of several commissions of the General Synod, such as Leer en Aktuele Sake (Doctrine and Actual Matters), Ampsbediening en Evangelisasie (Service of the Office and Evangelisation) and the Jeug-en Eredienskommissie (The Commission for Youth and Public Worship). He was also vice-chairman of the Psalm Revision Commission, later a member of the commission for the trial volume for hymns (Proefsangbundelkommissie) and later again a member of the Hymn Revision Commission.

\section{Academic contribution}

Vos was academically exceptionally active and between 1985 and 2001 he published in more than 41 academic journals. He also made contributions to more than 30 academic and popular religious books, wrote the texts of 12 hymns in the present hymn book of the Church, and published 4 volumes of poetry. He therefore made a remarkable contribution towards homiletics and liturgy, but also paid attention to hymnology (Müller 2002:124).

\section{Recognition for his work}

Vos was awarded for his work. In 1999 he received the Andrew Murray prize for theological subject literature for Die volheid daarvan I en II. In 2001 he received the Pieter van Drimmelen medal from the South African Academy for Science and Arts for his work on homiletics and the promotion of Afrikaans in theology. He also performed as host for renowned international academics (Müller 2002:124). At a promotion function in the Netherlands (commendation at the conferment of the doctoral degree to E.A. Postma on 30 June 2008), Professor Marcel Barnard placed Cas Vos in the same league as Mönnich, Allard Pierson, Gerardus van der Leeuw and G.J. Hoenderdaal as theologians who managed to integrate arts and the academy.

Professor Vos is also a member of national and international organisations in his subject field as well as of the South African Academy for Science and Arts. He has also performed at various national and international congresses as speaker and guest professor (Müller 2002:124).
In the meantime, Cas Vos has developed into an esteemed poet in Afrikaans literary circles. His volumes of poetry are recently being widely recognised and some of his poems are now indexed in the new Groot verseboek (an encompassing volume of renowned Afrikaans poets with André P. Brink as editor). An honour indeed!

From 1993 to 1999 Profs Vos and Müller were the only permanent full-time personnel in the DRC Department (Section B) of the Theological Faculty (Müller 2002:124).

\section{Professor Julian Müller Background}

Professor J.C. (Julian) Müller was appointed in July 1990 as professor in Practical Theology. Müller obtained his doctoral degree in homiletics, but with this appointment he was tasked to specialise in pastoral counselling and the deaconate. Consequently he developed courses in pastoral care and the deaconate on graduate and postgraduate level (Müller 2008). The course in pastoral family care, which he developed in 1992 at master's level, is still most popular and at least 12 students enrol annually. A significant percentage of these students continue towards the completion of a doctoral degree (Müller 2002:124). Presently, this department delivers more postgraduate students than the other departments of the Faculty together.

Müller's publications developed into two directions: firstly the narrative approach in pastoral counselling and secondly an emphasis on intercultural counselling. In both fields he has published more than 40 articles in scholarly journals and has written important books in which his research is evident. Some of his most well-known works are Gesinne van binne (Families from inside) (2002), Reis-geselskap (Fellow-travellers) (2000), Die kuns van pastorale gesprekvoering (The art of pastoral discourse) (2000) and Om tot verhaal te kom (To come to your wits again) (1996). Since 2000, Müller expanded his narrative approach to pastoral therapy towards a research methodology for practical theology. More recently the concept of a postfundamental practical-theological methodology was also discussed in publications. This interest took him to the interdisciplinary arena. In July 2008 he read a paper at the International Congress on Interdisciplinary Social Sciences. This paper was also published in the International Journal of Interdisciplinary Social Sciences. In 2009 he participated in a conference on New Directions in the Humanities in Beijing.

He has also published on general matters of the church and religion. For his book Die erediens as fees (Public worship as feast) he received the Andrew Murray prize in 1992. In 2006 he published Opstanding (Resurrection), which elicited a great deal of controversy in the media. He is co-editor of the series God, Mens en die Wêreld (God, Human and the World) and coeditor (with Hennie Pieterse and Cas Vos) of a textbook series for practical theology. He regularly contributes to columns in the daily newspapers.

\section{International recognition}

Müller is a member of several national and international organisations in his subject field. For a number of years he was the editor of the accredited specialist scholarly journal Praktiese Teologie in Suid-Afrika (Practical Theology in South Africa) and he was also chair of the Association for Practical Theology in South Africa for three terms. He has performed as speaker at several national and international congresses and has also presented a number of workshops. He is a member of the International Pastoral Care Network for Social Responsibility and has attended many of their congresses in Europe where he acted as speaker several times. The topics of the papers and lectures reflect time and again a sensitivity for the main issues of the day and the context within which practical theology is practiced.

In 1991 he read a paper in Accra that pertained to pastoral care in the African context. During April 1994 the first democratic 
elections in South Africa were held and Nelson Mandela became the first black state president. The years before 1994 were politically speaking - extremely turbulent, yet Müller in that year presented a workshop with the title Political violence as a communicative action: A pastoral systemic perspective.

During 2006 he took part in an international peace conference in Hiroshima, where he read a paper on South African perspectives on the peace processes (Müller 2008).

During study tours and other visits he gave presenations at the Texas Christian University, the Free University of Amsterdam, the Rijksuniversiteit of Utrecht, the Columbia Theological Seminary in Atlanta, USA, the Protestant Faculty in Rome (Facolta Valdensa) and two universities in Korea, namely Gwanshin and Sangkyul (Müller 2008).

\section{In touch with the church community}

Like his predecessors and colleagues, Professor Müller serves on several clerical commissions, especially with regard to youth ministry and public worship. From 2001 to 2004 he was a member of the synodal board of the DRC's Eastern Synod. He was also part of the Task Team for Homosexuality who had to advise the General Synod of 2007. Furthermore, he has a parttime pastoral consulting room and he is also a specialist pastoral therapist of the Lux Mundi DR Parish in Pretoria. Since 2007 Professor Müller has been the chair of the DR Lecturers' Council at the Faculty and in this capacity he also serves on the Executive Committee of the Curatorium.

\section{RESEARCH PROJECTS IN THE COMMUNITY}

In 2000 the Department formulated its mission as follows: 'To promote the following on the basis of a thorough and systemised theological practice: practical-theological reflection on the narratives in the society which relates to the community of believers; practical theological research which could result in refined practice; exposition to different practical theological disciplines for the student to develop theologically and with regard to skills in the ministry; community-directed programmes so that the results of research can contribute to the development of the community' (Müller 2002:124).

This mission was not only restricted to paper, but was practically expressed in the community-directed programme that was launched by the Department.

A group of 16 students involved themselves until the end of 2004 with an interdisciplinary project with the title 'The unheard stories about care and/or the lack of care by people infected and/or affected by HIV/Aids.' This project was funded by SANPAD, and institutions such as HOSPIVISIE participated in the programme with the aim to make homecare available to people who suffer as a result of Aids (Müller 2002:125; Müller 2008). This endeavour was followed up by a later project, specifically directed towards children affected by HIV and Aids. This was funded by the National Research Foundation.

Together with Professorss Ganzevoort (Netherlands), Demasure and Nadau (Canada), Professor Müller participates in a research project on posttraumatic spirituality.

\section{CONTINUING CHANGE IN THEOLOGICAL} TRAINING

In the meantime, the face of theological training in the country has been changing, and this has posed enormous challenges to the Department of Practical Theology. The change in training and education had its origins at the Faculty of Theology at the University of Pretoria.

Professor A.H. van Zyl pleaded for an integrated theological training in the DRC and that all subjects should be presented as a unity for future ministers of religion. The implication was that the previous seven-year course was reduced to a course that lasted only six years (Van der Watt 1987:182-183).

The General Synod of 1978 gave the green light in principle for a replanning of theological training with the view to a better integration of the existing two phases, whether this means that some theological subjects are included by literary studies, or whether the training is shaped towards one all-inclusive integrated theological course.

(Dutch Reformed Church 1978:920-921)

Since 1983, theological students were requested to complete a three-year BA Theology/Admission and thereafter a three-year theological course - called BD at the University of Pretoria, and BTh at Stellenbosch University and the University of the Free State.

In 2000 the two faculty sections (Netherdutch Reformed Church of Africa [NRCA] and DRC) amalgamated into one Faculty of Theology. In the beginning of 2000 Professor Vos accepted the deanship of the new Faculty in a temporary-fulltime capacity. Professor Müller became the head of Department and was the only permanent full-time staff member of the DRC in the Department. In the course of that year, Professor Yolanda Dreyer of the NRCA was appointed as permanent full-time coprofessor. For the most part, however, lectures were assigned to temporary part-time appointments.

To comply with the demands of church ministry, the following subjects are presently offered on BTh and MDiv levels: Introduction to Practical Theology, Homiletics, Pastoral Counselling, Liturgy, Parochial Charity, Hymnology, Parish Building, Youth Ministry and Faith, Ministry of the Gospel, Sociology of Religion, Psychology of Religion, Language Skills and Church Management. Pastoral Counselling focuses specifically on crisis, marriage, family and other forms of counselling (Müller 2002:124).

\section{A WORLD-CLASS PRACTICAL THEOLOGY}

In the nineties Professors Vos and Müller established and expanded the Department of Practical Theology to a department that is internationally competitive. They accomplished this by means of the many master's and doctoral students who choose to study at the Department and the national and international recognition of their publications. With the establishment of one multi-church faculty, the profile of the Department was enriched by the contributions of Professor Yolanda Dreyer and Maake Masango, a Presbyterian minister, who also joined the ranks. The international recognition of the Department was established and expanded in the following ways:

- Professor Gerben Heitink of the Free University of Amsterdam was appointed as honorary professor in the Department and in 2008 he also received an honorary doctorate from the University of Pretoria.

- Professors Hennie Pieterse (emeritus from Unisa) and Malan Nel, who are both internationally esteemed as practical theologians, were also appointed as honorary professors in the Department.

- Several well-known practical theologians from abroad were accommodated from time to time as guest lecturers and some worked here for longer periods, such as Karlijn Demasure from Nijmegen and Jerry Streets from Yale.

\section{REFERENCES}

Büchner, E.P., 2007, “"Ek het 'n roeping": Vrouepredikante se toelating in die Nederduitse Gereformeerde Kerk: 'n Kerkhistoriese en prakties-teologiese studie', Unpublished DD dissertation, Universiteit van Pretoria.

Dutch Reformed Church, 1978, Handelinge van die vyfde vergadering van die Algemene Sinode van die Nederduitse Gereformeerde Kerk, DRC, Bloemfontein. 
Dutch Reformed Church, 2008, Jaarboek van die Nederduitse Gereformeerde Kerke, Tydskriftemaatskappy, DRC, Wellington.

Heitink, G.,2008, 'Hermeneutiesch competent-Een Nederlandse bijdrage voor de Fakulteit Teologie van de Universiteit van Pretoria naar aanleiding van het mij op 18 April 2008 door deze universiteit uitgereikte eredoctoraat', Verbum et Ecclesia 29(2), 407-425.

Hofmeyr, J.H., 2002, 1938, "n Teologiese fakulteit vir Tukkies', in G. Hofmeyr (main ed.), NG Kerk 350: Eenhonderd bakens in die geskiedenis van die Nederduitse Gereformeerde Kerk 1652-2002, pp. 178-179, Lux Verbi BM, Wellington.

Jordaan, G., 1976, Deo Gloria. Jaarblad van die Teologiese Fakulteit (Afdeling B) van die Universiteit van Pretoria 37(36), Pretoria.
Kellerman, J.S., 1989, Lewenskets van prof JJ de Klerk, in J.A. Du Rand \& J.S. Kellerman (eds.), Diensknegte van die Koning: Huldigingsbundel ter ere van prof IJ de Klerk en prof EPI Kleynhans, pp. 1-2, Pro Christo-Publikasies, Bloemfontein.

Kok, V., 1976, Deo Gloria. Jaarblad van die Teologiese Fakulteit (Afdeling B) van die Universiteit van Pretoria 37(36), Pretoria.

Müller, J.C., 2002, 'Praktiese teologie', in P.B. van der Watt (ed.), Ad Destinatum IV. 1993-2000. Historiese ontwikkelinge en gebeure aan die Universiteit van Pretoria, pp. 123-125, University of Pretoria.

Van der Merwe, G. \& Viljoen, D., 1999, In memoriam: Jaarboek van die Nederduitse Gereformeerde Kerke. Feesboek, 150th edn., Tydskrifte Maatskappy van die Ned Geref Kerk, Cape Town.

Van der Watt, P.B., 1987, Die Nederduitse Gereformeerde Kerk 1905-1975, NGKB, Pretoria. 